\title{
Climate and Development
}

\section{Climate change, environmental stress and loss of livelihoods can push people towards illegal activities: a case study from coastal Bangladesh}

Istiakh Ahmed, Sonja Ayeb-Karlsson, Kees van der Geest, Saleemul Huq \& Joanne Catherine Jordan

To cite this article: Istiakh Ahmed, Sonja Ayeb-Karlsson, Kees van der Geest, Saleemul Huq \& Joanne Catherine Jordan (2019) Climate change, environmental stress and loss of livelihoods can push people towards illegal activities: a case study from coastal Bangladesh, Climate and Development, 11:10, 907-917, DOI: 10.1080/17565529.2019.1586638

To link to this article: https://doi.org/10.1080/17565529.2019.1586638

册 Published online: 05 Mar 2019.

Submit your article to this journal $₫$

Џ Article views: 268

Q View related articles $\llbracket$

View Crossmark data $\nearrow$ 


\title{
Climate change, environmental stress and loss of livelihoods can push people towards illegal activities: a case study from coastal Bangladesh
}

\author{
Istiakh Ahmed ${ }^{a}$, Sonja Ayeb-Karlsson $\mathbb{1}^{\mathrm{b}, \mathrm{c}}$, Kees van der Geest ${ }^{\mathrm{c}}$, Saleemul Huq $\mathbb{( 1 )}^{\mathrm{a}}$ and Joanne Catherine Jordan ${ }^{\mathrm{d}}$
}

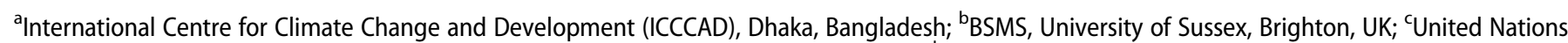
University - Institute for Environment and Human Security (UNU-EHS) Bonn, Germany; ${ }^{\mathrm{d}}$ Global Development Institute, The University of Manchester, Manchester, UK

\section{ABSTRACT}

This paper aims to understand how environmental stressors influence people's livelihood options in the coastal belt of Bangladesh. We argue that environmental stressors such as cyclones, riverbank erosion, salinity intrusion, and floods have negative impacts on people's lives by reducing their livelihood options. Twelve in-depth interviews (Livelihood Histories) and twelve Focus Group Discussions (FGD) based on two Participatory Rural Appraisal (PRA) tools (Village Timeline and Contextual Change) were carried out in three different sites in coastal Bangladesh were conducted under the study. Our study finds that when there are insufficient adaptation strategies to environmental stressors, many people turn to livelihoods banned by the government. These 'illegal livelihoods' include using fine mesh nets to collect shrimp fry in the rivers as well as logging in the Sundarbans. These people are often the poorestand vulnerable, and law enforcement only exacerbate their vulnerability. We end by concluding those that have turned to 'illegal livelihoods' as a result of detrimental environmental stressors should be viewed as a special category of vulnerable people by policymakers, and steps need to be taken to ensure resilience to different environmental stressors.
ARTICLE HISTORY

Received 27 March 2018

Accepted 17 February 2019

KEYWORDS

Illegal livelihoods;

environmental stress; resilience; climate change; Bangladesh

\section{Introduction}

Often denoted as one of the most climate vulnerable regions in the world, the southwest corner of Bangladesh is a complex socio-ecological system. It is situated on the east side of Bengal river delta, which is part of the larger Ganges-Brahmaputra river basin. With its deltaic fertile land and enormous numbers of river, people in Bangladesh are mostly involved with agriculture and fishing. The landscape is both volatile and active with rivers constantly shifting and changing their flow of direction. As such, the people of Bengal have always lived in a precarious situation facing a variety of natural hazards annually. The southwest region of Bangladesh in particular faces multiple hazards including annual flooding, coastal and riverbank erosion, and due to its funnel shaped coastline - experiences cyclones emerging from the Bay of Bengal every few years. Studies show that these cyclones, riverbank erosion and tidal floods have significant negative impact on agriculture and fishing at the coastal belt and are forcing people to change their livelihood to something else (Chambers, 2006; Ellis \& Freeman, 2004; Pouliotte, Smit, \& Westerhoff, 2009; Rabbani, Rahman, \& Mainuddin, 2013; Shamsuddoha \& Chowdhury, 2007). In this circumstance, catching shrimp fry from the wild source and wood logging from the sunderbans attract poor people of this region as these activities do not require much investment. However both the activities are banned by the government due to its negative consequences to the environment but many people are still getting involve with it (Rabbani et al., 2013).
Environmental disasters are not only a consequence of natural drivers but have also been exacerbated or fostered by human interventions in the region. For instance, water diversion upstream in India both exacerbates floods and river erosion in Bangladesh; as well as increases salinity intrusion into the Bengal delta (Mahmuduzzaman, Ahmed, Nuruzzaman, \& Ahmed, 2014). Additionally, the expansion of shrimp farming in the region limits people's livelihood opportunities and resultant soil salinity increase prevents them from partaking in subsistence agriculture (Paprocki \& Cons, 2014). Climate change will further these natural and man-made environmental hazards in a plethora of ways. The latest scientific research suggests global warming will heat up the oceans leading to both more intense cyclones in the Bay of Bengal, and more aggressive tidal waves increasing the frequency of coastal erosion (Agrawala, Ota, Ahmed, Smith, \& Van Aalst, 2003; Mahmood, 2012; Paul, 2015; Shamsuddoha \& Chowdhury, 2007). Research also suggests that there will be an increase of monsoon flows under current future predicted climate, which would increase the potential for flooding in the region. Low flows, however, may occur during drought periods, which would impact agricultural productivity and increase salinity intrusion (Whitehead et al., 2015). These facts combine together to render Bangladesh a highly vulnerable coastline (Nicholls et al., 2016, 2018). This is particularly true if their livelihood depends on a climate sensitive ecosystem (Corendea, Warner, \& Yuzva, 2012). The majority of the people living in southwest Bangladesh, for instance, are connected to either 
agriculture or fishing or both, which are highly dependent on the usual functioning of natural ecosystems.

Unfortunately, over the last several decades these livelihoods have gradually decreased pushing farmers and fishermen to look for alternative livelihoods (Shamsuddoha \& Chowdhury, 2007). A major reason for this is changing environmental stressors caused by both climate change and human-interventions. Models demonstrate that changes in salinity levels and temperatures due to increased $\mathrm{CO} 2$ in the atmosphere will limit crop productivity in the region, thereby impacting farmers (Lázár et al., 2015). Similarly, both agriculture and fisherydependent livelihoods will be most affected by climate-related floods and cyclones (Islam, Sallu, Hubacek, \& Paavola, 2014).

The spread of shrimp farming since the 1980s and 1990s, as previously mentioned, has in many cases rendered the traditional rice paddy uncultivable (Paprocki \& Cons, 2014). This has also created a high demand for shrimp fries supply and coastal rivers has become one major source for that. So while majority of the population in the coastal region partake in fishing, farming, or both as their primary means of livelihood, a significant proportion of the population rely on wild shrimp fry collection and every year around two billion shrimp fries are collected from wild sources in Bangladesh (Banks, 2003). Similarly approximately 0.52 million collectors are involved in wood logging for their livelihoods around the coastal belt due to lack of work opportunity (Hasan, Khan, Haque, Karim, \& Debnath, 2012). Both these activities are declared banned by the government. According to the code of conduct, for selected segments of the aquaculture industry in Bangladesh 2011, 'Farmer shall not use post larva (PL) of wild sources for the sake of environmental sustainability, bio-diversity and traceability, but will use PL from a certified hatchery' (Code of Conduct for selected segments of the Aquaculture industry in Bangladsh, 2011). Similarly, the Forest Act, 1927 states that,

any person who removes any timber from a reserved forest, shall be punishable with imprisonment for a term which may extend to five years and shall not be less than six months, and shall also be liable to fine which may extend to fifty thousand taka and shall not be less than five thousand taka, in addition to such compensation for damage done to the forest as the convicting Court may direct to be paid.

In reality, many people are still involved in these illegal activities, however. There have been many research studies on shrimp fry collection pattern or the quality and availability of shrimp fries (Azad, Jensen, \& Lin, 2009; De Graaf \& Xuan, 1998; Hoq, 2007) and on forest conservation and how the ban is being enacted (Islam \& Chuenpagdee, 2013; Islam \& Sato, 2012) but there is not enough literature exploring why these people are involving themselves in illegal livelihoods that negatively affect conservation efforts in the region.

The Gibika research to action project tried to understand livelihood resilience at the coastal belt and how local people adapt to different environmental stressors. This paper argues that different environmental stressors often create loss of livelihoods that people fail to or can only partially adapt to, which lead them towards vulnerability. Vulnerability and loss of livelihood influences people to take up alternative livelihoods, which are more open, easy to access and not highly climate sensitive. In this regard, wood logging from the Sundarbans or collecting wild shrimp fries with fine mesh net emerge as easy access alternative livelihood options allowing quick recovery from detrimental impacts of environmental stressors. Unfortunately, their situation only worsens if they get caught by the authorities, leading to greater social and economic vulnerability. This paper examines the complex relationships between different environmental factors, and how these are influencing more people to shift towards illegal livelihoods, potentially making them even more vulnerable than they were before. The paper recommends specifically addressing these people in the policy making process where they should be considered not as criminals but as a vulnerable group, and their livelihoods are made resilient against these environmental stressors through secure and diversified livelihood opportunities.

\section{Research sites and methods}

\subsection{Overview of the sites}

The Gibika Research to Action project has conducted repeated fieldwork in three study sites to gain a clearer idea regarding the climatic stressors communities are faced with and how people in these villages are responding to these environmental stressors. All three sites are in the coastal region of Bangladesh, and most of the people are involved in agriculture or fishing or both. The first site is Dalbanga south, situated at the bank of Bishkhali River in Barguna district, Barisal division. The second study site is Mazer Char, a char land situated in the middle of Baleshwari river in Pirojpur district, Barisal division. Being a char land, the soil of this site is very fertile since sediments generate it. However, riverbank erosion is eating up the land and decreasing the overall surface area. The third site is Gabtola, situated at the bank of Baleshwari river, in Bagerhat district, Khulna division. Gabtola has a concrete embankment; therefore riverbank erosion is no longer a problem in the site. However, during both cyclones Sidr (2007) and Aila (2009), the embankment was destroyed, flooding the surrounding areas.

\subsection{Methods}

The study conducted multiple field visits in the selected study sites, using qualitative methods, including Livelihood Histories and Participatory Rural Appraisal (PRA) tools. The main agenda of this study was to understand how diversely different environmental stressors impact the livelihood resilience of the study sites. This article highlights a more people $=$ oriented, qualitative research approach in the form of Livelihood Histories (LH) interviews and different PRA tools (Ayeb-Karlsson, van der Geest, Ahmed, Huq, \& Warner, 2016). These tools emphasize people - their state, adaptive strategies and challenges they face while dealing with environmental stress. It is crucial to understand different shocks, stressors and disasters from a social and anthropological point of view (OliverSmith, 1996), and in order to understand the complex rural development process and its relationship with livelihood dynamics, the qualitative tool Livelihood Histories (LH) has been applied in this study (Cannon, Twigg, \& Rowell, 2003; Scoones, 1998). Livelihood history tool is an important tool to understand livelihood dynamics as it captures individual 
life stories of the respondents to know about the changes in their livelihoods (Van der Geest, 2004). Semi-structured interviews have been conducted to identify the dynamic effects of different environmental stressors and shocks on people, their immediate coping strategies, recovery measures, challenges faced in the path of recovery and success rate of the measures. It also helped capture data on reconstructing changes in people's livelihoods over the years. At the same time, it is also important to identify why some people cannot adapt to the changing situation or why some people fail even though they undertake certain coping strategies. To capture their experiences the study applied different PRA tools such as Contextual change, Village timeline and Livelihood shock. Each of the tools enabled group discussions with separate groups of males and females and illustrate relationships between people's livelihoods and other related factors. Contextual change describes all the changes, both positive and negative, that have happened in the community over their lifetime and how these changes have affected their livelihoods (Dietz et al., 2013). Village timeline gives a historical picture of all the significant events that respondents remember, and Livelihood shock provides people's perspective of different hazards regarding the severity of these impacts on their livelihoods. Different environmental shocks and stressors help to identify the weaknesses and inability of different societies to recover and adapt to different features from their environment. The impacts of climate change are only framed as threats to nations and states by the policies. As a result, the debate has lost attention from the sufferings and coping strategies of people (Ayeb-Karlsson et al., 2016).

The study was conducted in 2014 and 2015 and a team of seven researchers were involved in collecting data. Bangla translators accompanied three foreign researchers.. Four researchers were dedicated to conducting PRA sessions and two researchers and one translator conducted the $\mathrm{LH}$ interviews. Below is a quick overview of the research tools used.

\subsubsection{Livelihood Histories}

Livelihood Histories are in-depth interviews focused on people's livelihoods and their periodic changes. The team conducted four livelihood history interviews including two male and two female informants at each site. Most of the interviews were on average, two to three hours long, consisting of around thirty questions. The main aim of the interviews was to understand the livelihood system, its changes and the impact of environmental stressors on it.

\subsubsection{Participatory Rural Appraisal}

Three Participatory Rural Appraisal (PRA) tools were implemented, all of them being Focus Group Discussion (FGD) sessions with about eight to twelve persons. The sessions were separately organized into groups for men and for women, during which the research team tried to draw reflections from people of different age, occupations, classes, levels of education. The duration of PRA sessions was one to two hours each.

- Contextual Change Exercise: This method was applied to understand whether the changes experienced in our study areas were positive or negative. Respondents were asked to identify their perception of these changes as either positive or negative and express their opinions on the reasons for these changes. Respondents expressed all the changes over time concerning eight domains (natural environment, agricultural change, built-up environment, human capital, economy, social and cultural change, and policy environment), each with several sub-domains (e.g. education under human capital, rainfall under natural environment). We selected this method to understand how people's lives and livelihoods have changed and what the major factors are behind these changes (Dietz et al., 2013).

- Village Timeline Exercise: Using this method we tried to make a list of major climatic events identified by the respondents and what effects these have had in their lives and livelihoods. In this method, it was essential to understand what the respondents consider to be important in the history and development of the village.

- Livelihood Shock Exercise: This method allowed us to learn about the underlying factors influencing the negative effects on people's livelihoods. We tried to understand how often these factors take place, how many people get affected by them and how severe these are. This process allowed us to provide a ranking of different hazards regarding the negative impact on people's livelihoods.

For this article, the three PRA tools were selected provide a comprehensive picture of people's livelihood systems and their changes over time, as well as the influencing factors and impacts of this phenomenon. Village timeline, in particular, gives a periodic view of major environmental stressors in these study sites.

\section{Understanding vulnerability and its relation to livelihood}

Vulnerability has always been viewed either on the basis of damage caused by a specific environmental stressor or by the condition before a hazard hits (Brooks, 2003). Vulnerability levels depend on the social and economic factors such as political economy, access to resources, assets and so forth. Social vulnerability shows the summation of the entire socio-economic condition of an individual, and when a disaster increases one's vulnerability, it disrupts the interaction of his different social factors (Brouwer, Akter, Brander, \& Haque, 2007; Warner, 2007).

Vulnerability and resilience are both co related and resilience depends on people's responsiveness and resisting or recovering capacity from the negative effects of the environment. When people cannot make their life and livelihoods resilient, they become vulnerable in the face of different environmental stressors.

Vulnerability and resilience both have important linkages with poverty (Adger, 1999; Moser, 1998; Moser, Norton, Stein, \& Georgieva, 2010). Often poor people are more vulnerable due to their powerlessness and limited access to resources. (Chambers, 1995; Chambers, 2006; Eriksen \& O’Brien, 2007). Poor people are vulnerable not only regarding their individual assets such as human and social capital but also as a result of how the community functions as a whole (Moser et al., 2010). Therefore, the resilience of an individual also depends 
on his access to resources, diversity of income sources available to him and his social status within the community (Adger, 1999). In this regard, livelihood diversity plays an important role in people's livelihood system in being sustainable (Ellis 1999). One's resilience also depends on their livelihood strength and therefore, people try to diversify their livelihoods as it increases the possibility to recover from an extreme event (Cannon, 1994). Alternative livelihoods are options which allow people to sustain against stresses when one's original means of livelihood does not provide adequate support (Scoones, 1998). Another significant proposed adaptation intervention is migration. While residents in the southwest region now seasonally migrate inwards to earn an income in the absence of job opportunities in the region, policymakers and scholars have suggested that voluntary migration can be a way out but this needs to be planned and a stable commitment should be in place (Warner et al., 2013). However, other scholars have argued that such migration efforts are part of a trend in disinvesting from the rural regions in the southwest (Paprocki, 2018).

\section{Result}

This section summarizes the main findings of this paper. It first describes the environmental stressors across the study sites, how they are affecting people's livelihoods and making them vulnerable. Later it illustrates people's responses and coping strategies against these stressors, specifically their involvement with illegal livelihoods and what people think about these illegal livelihoods and their roles in them.

\subsection{Environmental stressors, loss of livelihood and vulnerability in study sites}

The study has found that all three study sites face similar types of environmental hazards and informants have been dealing with these hazards for a long time. All the study sites are subject to regular cyclones, riverbank erosion, floods and shifting seasons. Informants from all study sites have also identified a slight increase in soil salinity in recent years. Only Gabtola now has a concrete embankment that prevents riverbank erosion.

In the livelihood shock exercise, informants from all sites ranked all the available hazards according to their impact on their livelihoods;

\begin{tabular}{lll}
$\begin{array}{l}\text { Environmental } \\
\text { Hazard }\end{array}$ & Rank & \multicolumn{1}{c}{ Reason } \\
\hline Riverbank erosion & 1 & $\begin{array}{l}\text { Riverbank erosion causes the most severe damage } \\
\text { to the villages because when they lose their } \\
\text { houses and crops along with croplands, it is never } \\
\text { recoverable. A lot of the time, these lands emerge } \\
\text { again after decades on the other side, but due to } \\
\text { complex land laws in Bangladesh, people are } \\
\text { usually unable to retrieve their lands. } \\
\text { It takes more than five years to recover from } \\
\text { damages to houses, crops and other livelihood } \\
\text { means in the aftermath of a cyclone. While, other } \\
\text { things such as loss of family, livestock as a result of } \\
\text { cyclones are unrecoverable. Following Sidr, the } \\
\text { situation has further worsened. The farmers now }\end{array}$ \\
&
\end{tabular}

(Continued)
Continued.

\begin{tabular}{|c|c|c|}
\hline $\begin{array}{l}\text { Environmental } \\
\text { Hazard }\end{array}$ & Rank & Reason \\
\hline & & $\begin{array}{l}\text { anticipate losses and are less willing to cultivate } \\
\text { vegetables and rice. }\end{array}$ \\
\hline Drought & 3 & $\begin{array}{l}\text { In recent years, it has been excessively dry. More dry } \\
\text { spells and sunshine affect crops during the } \\
\text { planting season. It affects winter crops. To cope } \\
\text { with drought, some people stop planting during } \\
\text { that time and move. Rich people can recover in } \\
\text { one year, but poor people need more time (more } \\
\text { than five years). Recovery requires improved } \\
\text { irrigation and fertilizers, which affects people's net } \\
\text { income and they are left with little money for } \\
\text { food, this subsequently results in food scarcity. } \\
\text { Significant effort is required for one to recover. }\end{array}$ \\
\hline Salinity intrusion & 4 & $\begin{array}{l}\text { Floods increase the level of salinity in the soil as well } \\
\text { as water bodies. Those that experience this salinity } \\
\text { suffer from degraded soil and land quality for } \\
\text { agriculture and fishery. Only a meagre } 10 \% \text { can } \\
\text { recover. }\end{array}$ \\
\hline Flood & 5 & $\begin{array}{l}\text { Floods are not as severe a problem for these } \\
\text { communities as they usually emerge during high } \\
\text { tide and leave with low tide. People's livelihoods } \\
\text { are not significantly affected as a result. However, } \\
\text { tidal surges that accompany a cyclone tend to } \\
\text { result in flooding that damages all the crops and } \\
\text { houses and kills livestock. }\end{array}$ \\
\hline
\end{tabular}

Respondents identified cyclone as one of the most regular and devastating natural hazards. One of the Livelihood History informants, in the study site of Mazer Char, has described how Sidr (2007) washed everything that she used to call home.

When I came back home, it was all gone. There was no sign of our home. I felt so alone. Then I thought Allah took everything from us and if he wants, he will give me back. Then the relief came and gave us food and support. [Female (1959), Mazer Char, 2014.05.25]

This example shows people's experience of a cyclone. Such hazards not only result in loss of life, debilitating someone emotionally but also the loss of livelihood, rendering one helpless. Similarly, in Dalbanga South, another Livelihood Histories informant expressed her Sidr experience where she lost the family fishing boat. During the onset of the cyclone, her brothers had been to the river to save their boat but could not rescue it, and one of the brothers was caught in the tidal surge. Her brother died a few days later, and the family lost one of their earning persons and an important means of livelihood, the fishing boat.

In the contextual change exercise, informants, at the study site of Mazer Char, mentioned that cattle are an important livelihood means in the char land, and people were quite well-off just by selling milk in the nearby marketplace. As land cultivation has been getting difficult due to increasing salinity, having a cow provides great support to a family. For some people, cattle serve as the main source of income, but during Sidr, a large number of them died causing many people to lose their means of livelihood.

With time, these cows multiplied into 19 cows and we were doing quite well until Sidr, when we lost 10 cows out of the 19. Before Sidr I was even planning to send my youngest son to Saudi Arabia to work. When the cyclone struck I could not manage to spare the 7-8 lac taka (1 lac $=100000$ taka $)$ needed to send him there. We lost everything. I just could not manage. He could not go there as we had planned. I was completely broke. With 19 cows, selling the milk they would produce (50 taka/litre) each day, together 
with the fish I managed to catch, I was pretty well off economically. [Male (1944), Mazer Char, 2014.05.24]

The informants were economically well-off selling cow milk before Sidr (2007) and tried very hard to save their cattle. One of the informants even lost his wife while trying to save the cows. In both cases, however, informants lost their livelihood means.

Informants in Contextual Change exercise also mentioned that cyclones and high tides also bring forth saline water, further damaging soil quality and productivity. Aila caused sudden and high salinity in the coastal lands and reduced the productivity of the land. Farmers are still facing difficulties in cultivating those lands, and the yield is very poor. One of the Livelihood Histories informants in Gabtola, described the aftermath of Aila.

In the time of Aila we did not really have any loss of life but the crop fields got completely destroyed due to saline water. Even now, we still cannot cultivate on many of our fields due to Aila and our land has not yet recovered. [Female (1967), Gabtola, 2014.05.27]

The informant experienced both Sidr and Aila; she described Sidr as a cyclone that caused immediate destruction and Aila having long-term effect on land as it brought along saline water that increased soil salinity. In the contextual change exercise, informants mentioned as light increase in soil salinity as a negative change; as a result, land cultivation has become difficult and less profitable.

Riverbank erosion is another major stressor that causes permanent loss of land. In the Contextual Change session, all the informants ranked riverbank erosion having the highest negative impact. At the session in Mazer Char, informants stated that riverbank erosion has increased in the last 20 years. After Sidr, erosion has increased even more and people are losing their lands more frequently. That is why land has become very important to acquire and often people get into disputes over land ownership and access. According to the informants, in 2001 there were 180 families in Mazer Char but afterwards, 25 families lost their lands between 2001 and 2002 because of riverbank erosion and they had nowhere to go within the village and had to leave the island.

According to the informants, losing land means losing both shelter and livelihood:

\footnotetext{
After the riverbank erosion we have not had a happy life. When I was a child, we used to eat rice from our own field. After that we have never eaten rice from our own field. / ... / Our scarcity came after the river bank erosion. Otherwise our fathers and grandfathers lived their life with enough food and everything. But now in our time, we are facing scarcity. [Female (1955), Dalbanga South, 2014.05.18]
}

'Once we had many lands but now we do not have any' is one commonly heard sentence in this region. Almost all the informants from all the interviews have described how they have lost all their land and became dependent on fishing or some form of agricultural activity.

Informants in Contextual Change exercise in Mazer Char also mentioned changes in rainfall patterns which affect their agricultural practices. The periods of rainfall have shifted, and nowadays there is hardly any rain during the summer season. Informants in Mazer Char are facing dry spells during the summer, which was not the case quite a few years ago. The winter rain is also less regular in all the sites. Farmers have to irrigate to cultivate the crops, but the water is high in salinty.

Previously life on Mazer Char was bounteous; lots of fishing, cows and milk, fertile land and crops. But the rainfall pattern has shifted. The dry season is hotter and drier, and more rain falls in the rainy season. This change affects the production of both Aman rice (rainy season) and cash crops (dry season). (Male, Contextual Change, MazerChar, 2014.05.25).

Due to all these environmental stressors and their negative impacts on livelihoods, people in the coastal belt lead a highly vulnerable life. Right after a disaster, people need money to recover from the losses incurred and often take out loans, entering into debt and further increasing their vulnerability. One of our Livelihood History informants, in the study site Gabtola, lost his house and boat in Sidr and had to take loans to repair his house.

I owe a debt of another $30,000-35,000$ taka to people in the village from whom I had borrowed money to deal with my loss during Sidr and after the riverbank erosion. [Male (1968), Gabtola, 2014.05.26]

To pay his loan back, this informant had to continue his previous livelihood means, but after losing his boat, it was impossible for him to carry on with his earlier livelihood choice and had to think of an alternative that would bring him quick money to feed his family and repay his loan. This scenario is quite a common in these study sites after a disastrous natural event.

\subsection{Coping with the stressors and involvement with illegal activities}

In all three study sites, informants described how people are dependent on natural resources for their livelihoods. Therefore, any disturbance to the ecosystem or any disastrous environmental event reduces livelihood options and pushes people to choose alternative livelihoods.

\footnotetext{
Before Sidr, farming was very good. The soil here is excellent. Sidr came and destroyed the crops and embankments, and the Friendship NGO rebuilt it, but Aila destroyed it again. So even though the soil is great, agriculture has been difficult: it is too risky because of the multiple threats. (Male, Contextual Change, Mazer Char, 2014.05.25)
}

The study showed that many people in Dalbanga South and Mazer Char are involved in shrimp fry collection from wild sources. While in Gabtola, many of them are involved with wood logging from the Sundarbans. One of our Livelihood Histories informants, in the study site Dalbanga South, described his shift in the following way:

\footnotetext{
Once, I cultivated my own land but now I am doing share cropping Lastly, I am catching shrimp fries now. I started this work because our income was not good enough and I do not have any strength to work as a day labor to cut mud. If I can catch at least 50 fries then I can buy the essential goods for my family. If I get 200 then I can buy something for my wife too. [Male (1944), Dalbanga South, 2014.05.19
}

The informant's family once had many lands, and their main livelihood was rice cultivation. Gradual riverbank erosion has eaten up all of their lands, and now he is living in his last 
piece of land. He also had to move from cultivating rice in his land to cultivating rice on others' land and collecting shrimp fries from the Bishkhali river. Similarly with cyclones, after losing the only livelihood means, informants mentioned that they had no other options but catching shrimp fries. One of our Livelihood History informants, in the study site Mazer Char, explained his situation:

It would have been better for me to have died in that cyclone. I lost my cows. I found some of their corpses in different places. Some of them were washed away. There was one cow left alive. What will I sell now? I lost my lands, so what will I plough now? I felt so helpless. Dying with the cyclone seemed better to me. I couldn't think of anything to do further/ ... / That is why I had to leave farming and now I have no option but to catch small shrimps. [Male (1936), Mazer Char 2014.05.24]

The main livelihood source of the informant was selling milk from his thirteen cows to the nearest market which gave him enough money to feed his family and also save some. Additionally, he had some land where he cultivated vegetable and earned some extra money. However, gradual riverbank erosion and cyclone Sidr destroyed all his livelihood means and put him in a situation where now he is living in another's house and catching shrimp fries to feed his family.

These are the stories that reflect most of the informants in Dalbanga South and Mazer Char. Normally people use a fine mesh net and pull it around the shore of the river. By doing this, they try to catch all the small fishes around the riverside, and then they sort out the shrimp fries from all the fish they get. After that, they sell these shrimp fries to the local buyers at a price of two to four taka each.

Informants in the Contextual Change session in Mazer Char mentioned, after Sidr, communities in the region have been subject to consecutive cyclones over the past few years. This susceptibility to cyclones is keeping many people away from agriculture and farming, and people are choosing to fish in the rivers. Sidr (2007) and Aila (2009) did not affect the number of shrimp fries in the river, so it became a very reliable livelihood means after the disasters. While salinity intrusion and changes in rainfall pattern have reduced the yield of crops, people catch shrimp fries as additional livelihood support, and stressors like cyclones and riverbank erosion make people completely dependent on shrimp fries.

Informants also described that since this does not need any investment rather than the net and most of the family members can collect it, and it has become one of the common livelihoods in the study sites.

Similarly, the study found that many informants in Gabtola are involved in wood logging from the Sundarbans. One of our Livelihood History informants, in the study site Gabtola, explained his reason behind wood logging from the Sundarbans,

We go to the Sundarbans not because of greed but to support our stomachs. If we do not go to the Sundarbans, then what will we do to feed our family. It is not an easy task to cut wood in the Sundarbans. It requires hard work. [Male (1968), Gabtola, 2014.05.26]

After cyclone Sidr, the family had lost everything and had to take loans to recover. With the high rate of interest, it was quite impossible for the informant to repay the money other than going to Sundarbans to cut trees. This activity provides a certain amount of money to quickly recover from losses after being hit by a disastrous climatic event. After losing his boat, he had an option to work on others' boats, but fishing in the river is always very uncertain. The informant explained this in the following way:

When it comes to fishing, you cannot say anything for sure. Some days, you might get a lot of fish and on other days you might get nothing. But with day labour in the Sundarbans, a fixed amount of money is guaranteed. [Male (1968), Gabtola, 2014.05.26]

Informants in our study sites know that wood logging and wild shrimp fry collection from wild sources are both illegal. Yet people choose these activities since they do not have any other feasible options. In their opinion, survival comes before the notion of legality.

\begin{abstract}
The Sundarbans is a restricted area. So, it is a crime to cut down any trees without notifying the forest department. If you cut down trees without doing so, you might be accused of having committed a crime and the forest department might file a forest case against you. [Male (1968), Gabtola, 2014.05.26]
\end{abstract}

We know it is not right to catch the small fishes but we have hungry stomachs. What do we do about that? If we can catch at least 50 small fishes, we can sell them for 200 taka. With that, we can buy rice and other foods. If we do not, then we have to starve. So we have problems on both sides. Everything is the wish of Allah (God). We are trapped in between two impossibilities. Do not know what to do./... /What the navy and the government says is also true, that if we do not catch the small fishes now, we can catch them later when they get bigger. But my hunger does not want to hear the fact. [Male (1939), Dalbanga South 2014.05.18]

Livelihood History informant in Dalbanga South mentioned that he tried to talk to the authorities about their situation, but the answers were always based on the law. Informants in Mazer char and Gabtola also mentioned that there once used to be a wood collecting process authorized by the government but access to the Sundarbans changed about ten years ago. The government has started restricting access and prevented them from working there, this affects the loggers, and now the level of unemployment is very high. The government did not do anything to help the affected people but just blocked the access. No compensations were given to the people dependent on the Sundarbans. In addition, there are no industry, mills or any factories in these areas. There is no diversity in the economy. These environmental and economic factors are compelling people to get involved with livelihood means that are banned by the government. Generally, the authorities treat wood loggers as criminals if they get caught and they are often sent to jail.

This boat is now gone. It is stuck with the forest department. I will now have to give 15,000 taka to the boat owner for losing his boat. At the same time, I might get a case filed against me as I went into the Sundarbans for logging without notifying the forest department and that is illegal. For the forest case, I will have to pay at least 20,000 taka to the chairmen to get rid of the case or I might end up in jail. [Male (1968), Gabtola, 2014.05.26]

Regardless, people still venture into the Sundarbans forest in search of resources to sell and collect shrimp fries from the river driven by the need to support their families. Law enforcement creates a cycle of vulnerability that people get trapped in 
and they anxiously anticipate another disastrous environmental hazard.

After Sidr I have become anxious. I cannot seem to relax. My head is never completely with me anymore. Especially on days like this, the weather is just like that day, when it happened. I feel the wild breeze coming in from the river and it forces me to remember. I cannot stand that breeze anymore. I become anxious. [Male (1968), Gabtola, 2014.05.26]

\section{Discussion}

This paper provides an understanding of how different environmental stressors push residents in southwestern Bangladesh to become involved in various illegal activities, thereby threatening the region's sustainability. The results present an understanding of how people become vulnerable due to these different environmental and socioeconomic stressors both related to climate change, natural hazards and human-made hazards. Loss of livelihood increases the vulnerability of these populations, leading them to search for alternative livelihoods. As such, in the coastal belt of Bangladesh shrimp fry collection has become one of the leading alternative livelihood options for those who were dependent on agriculture (Ahmed, Mallick, Ali, \& Rahman, 2002).

The study shows that different environmental stressors such as riverbank and coastal erosion, are causing people to lose their livelihood means at the coastal belt of Bangladesh. Also, frequent tidal floods have contributed to soil salinity, and land has become less productive regarding agriculture (Rabbani et al., 2013). In Bangladesh, land is the most important asset for an individual, especially those who are connected with agriculture. It not shelters them but for them it also ensures sustenance. Losing that land and livelihood means losing everything. Although coastal villages in Bangladesh are quite abundant concerning natural resources and most of the people were in the past involved with farming and fishing, environmental stressors have now put their livelihoods at risk, leaving little to no options for them (Pouliotte et al., 2009). Different research has already shown that medium farm people in the coastal belt are losing their lands and becoming small farm people and then non-farm people (Shamsuddoha \& Chowdhury, 2007). In addition to the land and livestock, another major assets that poor people have are their own bodies and labour potential, and people therefore try to choose alternative livelihood options that do not require that much economic investment but rather their physical labour (Chambers, 2006; Ellis \& Freeman, 2004).

Their vulnerability also connects to the broader political economy of resource use and access to resources (Adger, 2006). In the coastal region, poverty and high dependency on natural resources also contribute to increased vulnerability in people's lives (Alam \& Murray, 2005). Being a developing country, Bangladesh has weak socio-political structures, insufficient infrastructure and inadequate resource management, and at the same time, the state is unable to provide relevant social protection which increases vulnerability levels within a community (Cannon, 1994; Coirolo \& Rahman, 2014; Pouliotte et al., 2009). Since resources are limited, people fight for control of them and a significant proportion of people lose out in the battle. With the lack of electricity and established industries in the surrounding areas, there are no other jobs available for the people in our study sites. All these factors create a social vulnerability among the poor which influence them to choose livelihood options that are open and do not need much economic support (Kloos, Gebert, Rosenfeld, \& Renaud, 2013; Matthew, 2008).

Thus, in Dalbanga South and Mazer Char, a majority of the people are getting involved in collecting shrimp fries from wild sources. Due to salinity intrusion, shrimp cultivation has become popular at the coastal belt of Bangladesh and supplies for most of these shrimp farms come from wild shrimp sources. Shrimp farming has expanded significantly in the region since the 1980s, due to the high export value of shrimp and as a result, so has wild shrimp collection (Pokrant \& Reeves, 2003). However, in 2000, the Bangladesh government declared a ban on catching wild shrimp fries from the rivers due to it adverse effects on other fish species and presently it is illegal to do so (Islam et al., 2015). In our sites, people who have chosen to collect shrimp fries as an additional or alternative livelihood option to cope with environmental stressors. These people are usually very poor additionally most of them are landless too (Mahmood \& Ansary, 2013). For them, it is quite impossible to own a hatchery and cultivate shrimp fries. This vulnerability and unavailability of other feasible options make shrimp fry collection a lucrative choice for these people as it also has a high market demand.

Similarly, different illegal activities are also happening in the Sundarbans, and a vast number of people are involved (Kabir \& Muzaffar, 2002). Sundarbans plays a vital role in ensuring livelihoods for its surrounding communities where almost half the people depend on the forests directly, while the rest, indirectly (Chowdhury, 2010). Being nearby Sundarbans, Gabtola also belongs to the same category. Local people are involved with honey collection, collecting wood as fuel, wood logging. Most of these activities provide a meagre amount of money. Wood logging provides a good sum, but the government prohibits it. Now Bangladesh government has a high priority on increasing forest coverage in the country to at least $20 \%$ of its total land. While afforestation in different level is one major step taken by the government, reserving the existing forest is also has become one of their priorities (National forest policy, 1994). Therefore removing any sort of timber has become prohibited from the reserve forests. Earlier in the past, the local forest authorities would allow people to cut particular species of trees after paying a certain amount of money to the government. However, around ten years ago, the authorities closed that option, leaving all the workers unemployed. As a result, people had to seek alternative livelihood sources but being poor and illiterate; they had limited options to choose from, leaving them dependent on the Sundarbans again. Since Sundarbans is a reserve forest, people end up extracting resources illegally (Ahmed, 2008).

To prevent illegal activities, the government has taken and continues to take steps to address the issue (National fisheries policy Bangladesh 1998, National Forest policy Bangladesh 1994). Bangladesh fisheries department is responsible for all fisheries-related activities, and the administration department ensures proper law enforcement. However, when it comes to 
a coastal river or sea, the coast guard and Bangladesh Navy play a vital role in maintaining rules and regulations and law enforcement. Members of the Bangladesh Navy and the Coast Guard often roam around in different rivers and capture fishers who are catching fish with a banned net and catching shrimp fries with a fine mesh net. Most of the cases they burn the net and take the fishermen to prison. Similarly, the forest department arrests all the loggers from the Sundarban and take them to prison. In both the cases, fisheries department and forest department file a criminal case and if found guilty, can have six months to ten years of imprisonment. In many cases, accused individuals pay a significant bribe to avoid the continuation of a criminal case.

It is undeniable that both the activities are harmful to the overall environment; where catching shrimp fries kills hundreds of other fish fries and wood logging destroys the forest. From the government perspective, preventing these activities is a top priority and to do so, they have imposed laws restricting such activities. A failure to obey the law will have punishable consequences. A lack of insight of the local context has lead to ineffective planning and a lack of capacity making the situation even worse. Results section shows that these illegal activities only provide the bare minimum amount of income required for the family to survive. Therefore, without considering people's vulnerable situation, law enforcement actions such as burning illegal fishers' nets and imprisoning them only serves to increase their vulnerability. The same scenario applies when getting accused in a criminal case for wood logging. Due to all these factors, poverty turns into overall socioeconomic vulnerability, and law enforcement only worsens their vulnerability levels. While the above government interventions do provide temporary solutions, they stand to do more harm than good in the long run. (Corendea et al., 2012).

It is not a solution to call these people criminals; there is a need to move beyond legal definitions (Green, Ward, \& McConnachie, 2007). Government interventions should aim to ensure people's livelihood resilience and enhance their adaptive measures. Livelihood resilience depends on various factors such as severity of hazards, previous condition, preparedness, the time between hazards and people always try to make their livelihood resilient by having an alternative livelihood option to secure their income source (Scoones, 1998). It is therefore important to develop a people-centered perspective on livelihood resilience and understanding on anthropogenic factors of that specific area which not only emphasize on the ability to absorb the shock but also to improve the livelihood condition despite disturbance (Ayeb-Karlsson et al., 2016; Obiri \& Damnyag, 2011). Policies should also consider the diversity of local environmental, social and economic factors since people work within these factors (Pokrant \& Reeves, 2003). These will help local communities to alleviate their vulnerability to different environmental stressors and to ensure resilient livelihoods. Bangladesh has achieved immense success in saving lives during environmental disasters but there now needs to be an increased focus on saving people's livelihoods as well. Also, the availability of secure alternative livelihood options that are legal will increase the overall levels of resilience. Livelihood diversification contributes to reducing the impacts of environmental stressors in people's lives (Brooks \& Adger, 2004; Ellis 1999).

\section{Conclusion}

This article sheds light on the causal relationship between environmental change stress and people's livelihoods in the coastal belt of Bangladesh due to the mechanism that links individuals to depend on ecosystems for their income and everyday life (Corendea et al., 2012). Furthermore, this research explores the ways in which perceived and real environmental risks in the region are key drivers in producing illegal livelihood responses that threaten the locale's sustainability. Being in close proximity to rivers and the Sundarbans, a significant portion of the population have started to collect wild shrimp from the river and logwood from the Sundarbans. If anyone is caught undertaking these illegal activities, authorities punish them, occasionally sending them to jail. This type of law enforcement ultimately further exacerbates the adverse situation faced by such poor and vulnerable group. This research attempts to establish the relationship residents have to their ecosystems; and when their traditional livelihoods are threatened by a variety of natural and human-made hazards, including climate change, they shift to alternative livelihoods that similarly depend on their ecosystem, even though they have been deemed illegal.

As such, appropriate policy interventions should aim to provide climate resilient, environmentally sustainable livelihoods to the people of coastal Bangladesh. Since the shift towards illegal livelihoods threatens the region's sustainability, interventions should explore and promote forms of livelihood that do not threaten the local environment. This includes various forms of skills training that would allow residents to either remain in their home villages or migrate elsewhere in Bangladesh for more stable jobs, either seasonally or permanently. Policies could provide a social safety net during the time required for skills training and capacity building. This would allow residents to acquire new skills necessary for different alternative livelihoods comfortably. At the macro-level, this may require rethinking investments into the southwest region of Bangladesh that provide ample job opportunities and lifestyle satisfaction for residents.

The current practice of criminalizing these illegal activities only further exacerbates the vulnerability of the already climate vulnerable. This paper argues instead of viewing those who partake in these illegal activities as simply criminal; they should be viewed in the context of the various environmental stressors that have negatively impacted their traditional livelihoods. In this way, implementing new policy interventions would support the creation of climate resilient and environmentally sustainable livelihoods for these poor and vulnerable populations.

\section{Disclosure statement}

No potential conflict of interest was reported by the authors.

\section{Notes on contributors}

Istiakh Ahmed is the Coordinator for the Resilient Livelihoods Programme at ICCCAD. He has completed both his BSS and MSS in Anthropology 
from Jahangirnagar University and has an in-depth experience in social research and its different methodologies. Istiakh joined ICCCAD in 2014 and managed several projects including Gibika (a five-year research to action project), Cap water, Governance for Climate Resilience, and currently, he is managing Panii Jibon project from February 2018. Throughout this period he was actively involved with conducting environmental and social research, capacity building, advocacy and above all guiding the entire team. Working with ICCCAD has given him a closer understanding over Climate Change and environmental aspects of the social issues. Istiakh has also been actively involved with giving trainings on climate change basics and management of climate change-related projects to youth for many years. While completing his university studies, Istiakh has been involved with a number of social research projects with Plan International and an individual consultant, Dr Zahir Ahmed (Professor of Jahangirnagar University and Senior research fellow of SOAS University). Before joining ICCCAD, Istiakh worked with BRAC Development Institute (BDI), BRAC University on projects focused on primary education and internal migration in Bangladesh. His research interest areas are livelihood resilience, Climate Change vulnerabilities, Climate Change adaptation, environmentally induced migration and social understanding and belief system. Istiakh has published several peer-reviewed journal article as lead author and co-author, working papers, policy briefs, newspaper articles and bulletins and presented his research work in many international conferences.

Dr Sonja Ayeb-Karlsson is a Lecturer in Global Health at BSMS, University of Sussex who researches (im)mobility decisions, migration, health and well-being in the context of environmental stress and climatic changes. She is also a Senior Researcher at UNU-EHS and part of WG1 and WG2 in the Lancet Countdown.

Between the years 2013 and 2018, she worked in Bangladesh as a project manager in collaboration with ICCCAD and MRF. Her research combined quantitative and qualitative methods such as $\mathrm{Q}$, survey design, storytelling methodology, personal life history interviews and discourse analysis with the aim to further develop anthropological research approaches that support the interaction with people facing climatic stress, while exploring alternative ways to communicate research findings through mediums of photography, visual communication and photo films.

Prior to this, she was involved in a community-led initiative in Argentina that focused on the empowerment and human rights of ethnic minority groups in the northern areas of the country. She was selected to represent Stockholm on the national board of the Swedish Association of International Affairs in 2008. While completing her university studies in Brazil, Dr Ayeb-Karlsson dedicated a considerable amount of time to urban development and educational initiatives in Rio de Janeiro's favelas. At the Swedish Embassy in Brazil, she was responsible for organizing a seminar on Corporal Punishment of Children with the Ministry of Human Rights and Save the Children Sweden in the Brazilian National Congress in 2011. Discussions following the seminar lead up to the agreement of a new article on Corporal Punishment Prohibition in 2014 which made Brazil the largest country in the world to sign such a prohibition.

Including Bangladesh, Germany, Argentina and Brazil, Dr Ayeb-Karlsson has also lived, worked, and studied in England and Australia. She also has extensive international experience, having visited about 65 countries and has spent a large amount of time in South America, South as well as Southeast Asia. She is fluent in English, Swedish, Spanish and Portuguese with basic language skills in German and Bengali.

In 2015, she joined the work of the Lancet Commission and the Lancet Countdown that is tracking the connections between climate change and public health until 2030. Here she is part of WG1 and WG2 and mainly studies the linkages between climate change, mental health, migration and disasters; she is also the Latin and South American spokesperson and works closely with the Brazilian partner organizations in São Paulo and Porto Alegre.

Dr Ayeb-Karlsson is well-published including peer-reviewed articles in Ambio, Disasters, Sustainability Science and The Lancet. Her teaching in the areas of Global Health, Geography and Development Studies at BSMS, University of Sussex, and IDS includes the following undergraduate courses: Environmental Management and Sustainable Development
(L7003), Disaster, Environment and Development (005DA), Skills and Concepts in Geography I-II (002GR/F8509) and the Postgraduate Master courses: Climate Change: Impacts and Adaptation (838F8), and Climate Resilient Development (CRD), at the University of Sussex and IDS, as well as the Postgraduate Master courses: Global Health Msc (BSMS), Risk Management in the Context of Climate Change (UM6/JM9-2) at the University of Bonn and UNU-EHS.

Kees van der Geest $(P h D)$ is a human geographer who studies the impacts of climate change, human mobility, environmental change, adaptation, livelihood resilience and rural development. Key features of his work are the people-centred perspective and the mixed-method approach combining quantitative and qualitative research tools. His work has contributed substantially to expanding the empirical evidence base on migrationenvironment linkages and impacts of climate change beyond adaptation ("loss and damage").

Kees has extensive fieldwork experience, mostly in Ghana (5 years), but also in Burkina Faso, Vietnam, Bangladesh, Nepal, Marshall Islands and Bolivia. He coordinated research in many other countries across the Global South. Since 2012 he has been working as a senior researcher at United Nations University Institute for Environment and Human Security in Bonn (UNU-EHS). In the 'Migration and Environment' section at UNU-EHS, he leads the work on migration, livelihood resilience and loss and damage from climate change. Between 2014 and 2017, he also co-organized the annual Resilience Academy, which is a network of approximately 100 young professionals working on resilience, loss and damage, and human mobility in the context of global environmental change. From 2016 to 2018, he has been on a part-time secondment to the University of Hawaii, where he was involved in a research project about migration and environment linkages in the Republic of the Marshall Islands.

Kees studied at the University of Amsterdam (human geography) and a semester at the University of Sussex (migration studies). His Master's thesis and $\mathrm{PhD}$ thesis were published as monographs by the African Studies Centre. Several chapters of his $\mathrm{PhD}$ thesis about migration-environment linkages in Ghana have been published in international journals, such as International Migration, Africa, Environment \& Urbanization and Forced Migration Review. Two articles from his $\mathrm{PhD}$ are in the top 50 of most influential articles on the relation between migration and the environment according to ISI web of knowledge.

From 2006 to 2012, Kees worked as a lecturer and researcher at the University of Amsterdam. He taught courses on environment and international development and his research covered the fields of migration, environment and rural development. In this period, he also worked as an independent research consultant. Among his clients have been the Food and Agriculture Organization (FAO) of the United Nations, the Royal Tropical Institute in Amsterdam, CARE International, DFID Ghana and the Foresight programme of the UK Office for Science.

Kees has also been active as documentary film maker. His first, award-winning, documentary was screened at over 20 international film festivals worldwide. His second documentary received a nomination for the Holland-doc Jury Award of the Dutch Film Festival and has been watched more than 2.5 million times online.

Dr Saleemul Huq is the Director of the International Centre for Climate Change \& Development (ICCCAD) since 2009. Dr Huq is also a Senior Fellow at the International Institute for Environment \& Development (IIED), where he is involved in building negotiating capacity and supporting the engagement of the Least Developed Countries (LDCs) in UNFCCC including negotiator training workshops for LDCs, policy briefings and support for the Adaptation Fund Board, as well as research into vulnerability and adaptation to climate change in the least developed countries. Dr Huq has published numerous articles in scientific and popular journals, was a lead author of the chapter on Adaptation and Sustainable Development in the third assessment report of the Intergovernmental Panel on Climate Change (IPCC), and was one of the coordinating lead authors of 'Inter-relationships between adaptation and mitigation' in the IPCC's Fourth Assessment Report (2007). Prior to this, he was at Bangladesh Centre for Advanced Studies (BCAS) where 
he was in charge of management and strategy of the organization. In 2000, he became an Academic Visitor at the Huxley School of Environment at Imperial College in London.

Dr Joanne Catherine Jordan is affiliated with the Global Development Institute, The University of Manchester, Manchester, UK. She is an environmental social scientist with over 10 years of experience as a researcher on climate change adaptation. Much of this work is based on intensive empirical research at the local level, mostly in Bangladesh and, more recently, India. She specializes in climate change resilience and vulnerability, risk perception and culture, and climate change communication and knowledge exchange for impact.

She is an Independent Research Consultant, Honorary Research Fellow at The University of Manchester, and a Visiting Researcher at the International Centre for Climate Change and Development. Prior to this she was a Lecturer at the University of Manchester, a Post-doctorate Research Fellow at the Institute for Sustainable Development and International Relations at Sciences Po in Paris, a Research Assistant at Queen's University Belfast, and has worked at a range of not-for-profit organizations in Cambodia, Peru and Belize.

\section{ORCID}

Sonja Ayeb-Karlsson (DD http://orcid.org/0000-0001-6124-2730 Saleemul Huq (D) http://orcid.org/0000-0002-9398-973X

\section{References}

Adger, W. N. (1999). Social vulnerability to climate change and extremes in coastal Vietnam. World Development, 27(2), 249-269.

Adger, W. N. (2006). Vulnerability. Global Environmental Change 16, $268-$ 281. Elsevier Ltd.

Agrawala, S., Ota, T., Ahmed, A. U., Smith, J., \& Van Aalst, M. (2003). Development and climate change in Bangladesh: Focus on coastal flooding and the Sundarbans. France: OECOD.

Ahmed, A. I. M. U. (2008). Underlying causes of deforestation and forest degradation in Bangladesh. Amsterdam: Global Forest Coalition (GFC).

Ahmed, S. A., Mallick, D. L., Ali, M. L., \& Rahman, A. A. (2002). Literature review on Bangladesh Shrimp. Individual partner report for the project: Policy research for sustainable shrimp farming in Asia (PORESSFA), a comparative analysis of Bangladesh, India, Thailand and Vietnam with Particular Reference to Institutional and Socio-economic Aspects. European Commission INCO-DEV Project PORESSFA No.IC4-200110042, CEMARE University of Portsmouth UK and BCAS, Dhaka, Bangladesh.

Alam, M., \& Murray, L. A. (2005). Facing up to climate change in South Asia. (118). London: International Institute for Environment and Development.

Ayeb-Karlsson, S., van der Geest, K., Ahmed, I., Huq, S., \& Warner, K. (2016). A people-centred perspective on climate change, environmental stress, and livelihood resilience in Bangladesh. Sustainability Science, 11 (4), 679-694.

Azad, A. K., Jensen, K. R., \& Lin, C. K. (2009). Coastal aquaculture development in Bangladesh: Unsustainable and sustainable experiences. Environmental Management, 44(4), 800-809.

Banks, R. (2003). Brackish and Marine Water Aquaculture. Report on Fisheries Sector Review and Future Development. Bangladesh: Department of Fisheries, Matshya Bhaban, Dhaka 1000.

Brooks, N. (2003). Vulnerability, risk and adaptation: A conceptual framework. Tyndall Centre for Climate Change Research Working Paper, 38, $1-16$.

Brooks, N., \& Adger, W. N. (2004). Assessing and enhancing adaptive capacity. In B. Lim \& E. Spanger-Siegfried (Eds.), Adaptation policy frameworks for climate change: Developing strategies, policies and measures (pp. 165-182). Cambridge: UNDP, Cambridge University Press.

Brouwer, R., Akter, S., Brander, L., \& Haque, E. (2007). Socioeconomic vulnerability and adaptation to environmental risk: A case study of climate change and flooding in Bangladesh. Risk Analysis, 27(2), 313-326.
Cannon, T. (1994). Vulnerability analysis and the explanation of 'natural' disasters. Disasters, Development and Environment, 1, 13-30.

Cannon, T., Twigg, J., \& Rowell, J. (2003). Social vulnerability, sustainable livelihoods and disasters (pp. 1-63). London: DFID.

Chambers, R. (1995). Poverty and livelihoods: Whose reality counts? Environment and Urbanization, 7(1), 173-204.

Chambers, R. (2006). Vulnerability, coping and policy (editorial introduction). IDS Bulletin, 37(4), 33-40. Anthology, Institute of Development Studies.

Chowdhury, M. T. A. (2010). Resource-dependent livelihoods in the Sundarbans. (CRBOM Small Publications Series No. 18).Center for River Basin Organizations and Management, Solo, Central Java, Indonesia.

Code of conduct for selected segments of the aquaculture industry in Bangladesh. (2011). Department of fisheries government of Bangladesh and Bangladesh shrimp and fish foundation.

Coirolo, C., \& Rahman, A. (2014). Power and differential climate change vulnerability among extremely poor people in Northwest Bangladesh: Lessons for mainstreaming. Climate and Development, 6(4), 336-344. doi:10.1080/17565529.2014.934774

Corendea, C., Warner, K., \& Yuzva, K. (2012). Social vulnerability and adaptation in fragile states. (Publication series of UNU-EHS No. 11). Bonn: United Nations University Institute of Environment and Human Security.

De Graaf, G. J., \& Xuan, T. T. (1998). Extensive shrimp farming, mangrove clearance and marine fisheries in the southern provinces of Vietnam. Mangroves and Salt Marshes, 2(3), 159-166.

Dietz, T., Bymolt, R., Bélemvire, A., van der Geest, V., de Groot, D., Millar, D., ... Zaal, F. (2013). PADev guidebook: Participatory assessment of development. Amsterdam: KIT Publishers.

Ellis, F. (1999). Rural livelihood diversity in developing countries: Evidence and policy implications. Overseas Development Institute. Natural Resource Perspectives, 40, 1-10.

Ellis, F., \& Freeman, H. A. (2004). Rural livelihoods and poverty reduction strategies in four African countries. Journal of Development Studies, 40 (4), 1-30.

Eriksen, S. H., \& O’Brien, K. (2007). Vulnerability, poverty and the need for sustainable adaptation measures. Climate Policy, 7(4), 337-352.

Green, P., Ward, T., \& McConnachie, K. (2007). Logging and legality: Environmental crime, civil society, and the state. Social Justice, 34(2 (108)), 94-110.

Hasan, M., Khan, M. S. K., Haque, M. A., Karim, E., \& Debnath, P. P. (2012). Livelihood strategies of Tiger shrimp post Larvae collectors in Bakkhali river Estuary, Cox's Bazar of Bangladesh. International Journal of Sustainable Agricultural Technology, 8(9), 01-07.

Hoq, M. E. (2007). An analysis of fisheries exploitation and management practices in Sundarbans mangrove ecosystem, Bangladesh. Ocean \& Coastal Management, 50(5-6), 411-427.

Islam, K., \& Sato, N. (2012). Deforestation, land conversion and illegal logging in Bangladesh: The case of the Sal (Shorea robusta) forests. iForestBiogeosciences and Forestry, 5(3), 171-178.

Islam, M. M., Abdulla-Al-Asif, S. V., Zafar, M. A., Sharif, B. N., Rahman, M. H., \& Shahriyar, S. (2015). Socio economic status of fry collectors at Sundarbans region. International Journal of Fisheries and Aquatic Studies, 3(2), 89-94.

Islam, M. M., \& Chuenpagdee, R. (2013). Negotiating risk and poverty in mangrove fishing communities of the Bangladesh Sundarbans. Maritime Studies, 12(1), 7.

Islam, M. M., Sallu, S., Hubacek, K., \& Paavola, J. (2014). Vulnerability of fishery-based livelihoods to the impacts of climate variability and change: Insights from coastal Bangladesh. Regional Environmental Change, 14(1), 281-294.

Kabir, D. S., \& Muzaffar, S. B. (2002). The review of the present state of protected areas of Bangladesh. Bangladesh Environment, 2002, 389-403.

Kloos, J., Gebert, N., Rosenfeld, T., \& Renaud, F. (2013). Climate change, water conflicts and human security: Regional assessment and policy guidelines for the Mediterranean, Middle East and Sahel (Report no 10). Bonn: United Nation University Institute for Environment and Human Security (UNU-EHS).

Lázár, A. N., Clarke, D., Adams, H., Akanda, A. R., Szabo, S., Nicholls, R. J., ... Moslehuddin, A. Z. M. (2015). Agricultural livelihoods in coastal 
Bangladesh under climate and environmental change-A model framework. Environmental Science: Processes \& Impacts, 17(6), 1018-1031.

Mahmood, S. A. I. (2012). Impact of climate change in Bangladesh: The role of public administration and government's integrity. Journal of Ecology and the Natural Environment, 4(8), 223-240.

Mahmood, S. S., \& Ansary, B. S. (2013). Shrimp fry collection as alternative livelihood: A case study on the southwest coastal region of Bangladesh. ASA University Review, 7(2), 139-149.

Mahmuduzzaman, M., Ahmed, Z. U., Nuruzzaman, A. K. M., \& Ahmed, F. R. S. (2014). Causes of salinity intrusion in coastal belt of Bangladesh. International Journal of Plant Research, 4(4A), 8-13.

Matthew, R. A. (2008). Resource scarcity: Responding to the security challenge. New York: International Peace Institute.

Moser, C., Norton, A., Stein, A., \& Georgieva, S. (2010). Pro-poor adaptation to climate change in urban centers. Washington, DC: World Bank.

Moser, C. O. N. (1998). The asset vulnerability framework: Reassessing urban poverty reduction strategies. World Development, 26(1), 1-19.

National Fisheries policy. (1998). Bangladesh.

National Forest policy. (1994). Bangladesh.

Nicholls, R. J., Brown, S., Goodwin, P., Wahl, T., Lowe, J., Solan, M., ... Merkens, J.-L. (2018). Stabilization of global temperature at $1.5^{\circ} \mathrm{C}$ and $2.0^{\circ} \mathrm{C}$ : Implications for coastal areas. Philosophical Transactions of the Royal Society A: Mathematical,Physical and Engineering Sciences, 376 (2119), 20160448.

Nicholls, R. J., Hutton, C. W., Lázár, A. N., Allan, A., Adger, W. N., Adams, H., ... Salehin, M. (2016). Integrated assessment of social and environmental sustainability dynamics in the Ganges-Brahmaputra-Meghna delta, Bangladesh. Estuarine, Coastal and Shelf Science, 183, 370-381.

Obiri, B. D., \& Damnyag, L. (2011). Socio-economic contribution of illegal chainsaw milling to the Ghanaian rural economy. Ghana J. Forestry, 27, $50-67$.

Oliver-Smith, A. (1996). Anthropological research on hazards and natural disasters. Annual Review of Anthropology, 25, 303-328.

Paprocki, K. (2018). Threatening dystopias: Development and adaptation regimes in Bangladesh. Annals of the American Association of Geographers, 108(4), 1-19.
Paprocki, K., \& Cons, J. (2014). Life in a shrimp zone: Aqua- and other cultures of Bangladesh's coastal landscape. The Journal of Peasant Studies, 41(6), 1109-1130.

Paul, S. K. (2015). Post-cyclone livelihood status and strategies in coastal Bangladesh. Rajshahi University Journal of Life \& Earth and Agricultural Sciences, 41, 1-20.

Pokrant, B., \& Reeves, P. (2003). Work and labour in the Bangladesh brackish-water shrimp export sector. South Asia: Journal of South Asian Studies, 26(3), 359-389.

Pouliotte, J., Smit, B., \& Westerhoff, L. (2009). Adaptation and development: Livelihoods and climate change in Subarnabad, Bangladesh. Climate and Development, 1(1), 31-46.

Rabbani, G., Rahman, A., \& Mainuddin, K. (2013). Salinity-induced loss and damage to farming households in coastal Bangladesh. International Journal of Global Warming, 5(4), 400-415.

Scoones, I. (1998). Sustainable rural livelihoods: A framework for analysis. (IDS working paper, 72). Institute of Development Studies.

Shamsuddoha, M., \& Chowdhury, R. K. (2007). Climate change impact and disaster vulnerabilities in the coastal areas of Bangladesh. Dhaka: COAST Trust.

The Forest Act, 1927. (1927). Bangladesh.

Van der Geest, K. (2004). "We're managing!" Climate change and livelihood vulnerability in north-west Ghana. Leiden: African Studies Centre.

Warner, K. (2007). Perspectives on social vulnerability. (editorial introduction). Source no. 6. Bonn: United Nations University Institute for Environment and Human Security (UNU-EHS).

Warner, K., Afifi, T., Kälin, W., Leckie, S., Ferris, B., Martin, S. F., \& Wrathall, D. (2013). Changing climate, moving people: Framing migration, displacement and planned relocation. (Policy Brief No. 08) Bonn: United Nations University Institute of Environment and Human Security (UNU-EHS).

Whitehead, P. G., Barbour, E., Futter, M. N., Sarkar, S., Rodda, H., Caesar, J., ... Salehin, M. (2015). Impacts of climate change and socio-economic scenarios on flow and water quality of the Ganges, Brahmaputra and Meghna (GBM) river systems: Low flow and flood statistics. Environmental Science: Processes \& Impacts, 17(6), 1057-1069. 